\title{
Technique propose for integration and compatibility of traffic computers and local traffic control equipment installed in Bogota D.C. to a traffic central with open protocol under AENOR norms, using the currently communication network
}

\author{
[Chavez Esau, Tarazona_Bermudez G; Rodriguez Jose]
}

\begin{abstract}
The mobility inside a city is an indicator of the life quality of his population. When the technological infrastructure in whish are supported the traffic systems hasn't enough capabilities, makes a deterioration in the individual capabilities for travel inside his environment, The traffic lights system in Bogota needs a upgrade process because it count whit technological platforms with more than 30 years of service. This article shows the techniques characteristics of the traffic computers and local traffic control equipment in existence in the traffic lights system of Bogota and projected a minimal requirement for the integration of the infrastructure of the traffic lights inside a traffic intelligent system (SIT)
\end{abstract}

Keywords- Mobility, traffic lights, transport, traffic control equipment, traffic intelligent system, traffic management centers

\section{Introduction}

The traffic control equipment, currently installed in the city Bogota D.C., which are commanded by the traffic management centers are of different technologies and fabrication dates inside of it stand out the traffic control equipment Siemens GE, Siemens MP, Siemens MR, Sitraffic C800V/C800Vk and Siemens Sitraffic C900V [1]. In the same way also of the costs caused by the communication lost with the centrals makes that the control equipment installed in the road corridors are uncoordinated and caused overcrowding and vehicular chaos.

\section{Esau Chavez}

Universidad Distrital Francisco Jose de Caldas Bogotá D.C, Colombia

Giovanny Mauricio Tarzona B. Ph.D.

Universidad Distrital Francisco Jose de Caldas Bogotá D.C, Colombia

Jose Ignacio Rodriguez.

Universidad Distrital Francisco Jose de Caldas Bogotá D.C, Colombia
Given the circumstances the traffic lights system in the city and the low existing information about this topic the proposal of paper is the elaboration of a protocol which allows the interconnection between the control equipment existing in the traffic lights systems of Bogota D.C City and it arises the technical requirements with the goal of allows a migration of the traffic computers and the local traffic control system equipment of traffic lights of Bogota D.C. to a ITS based in a AENOR protocol.

\section{Interconnection between existing equipment:}

The interconnection between centrals its perform through a LAN network, point-to -point between the three different control centers, which allows that an access remote unit enter to the traffic computer data without exchange information between the three traffic control systems computers of Bogota city.

With which it can have the control of all the capability installed in the city from a same management center. The interconnection trunks are copper wires gauge 6 of 20 telephonic pairs [2], whereby are transmitted the data between the monitoring remote terminal and the traffic control computer and the time synchronism data which transmits hours, minutes, seconds and the synchronism cadence pulse of the system.

The media transfers the information through Fast Frequency Shift keying FFSK, with a baud rate 2600, a word length of 16 bit and manufacturer property code.[3]. The modulation FFSK is characterized for adapting to industrial communication networks above high level noise systems above telephonic pairs and allows the transduction through impedance coupling transformers with a capability of transmit until 1300 meters[4]. 
Proc. of the Fourth International Conference on Advances in Computing, Electronics and Communication - ACEC 2016. Copyright ( $)$ Institute of Research Engineers and Doctors. All rights reserved.

ISBN: 978-1-63248-113-9 doi: 10.15224/ 978-1-63248-113-9-55

\begin{tabular}{|c|c|c|}
\hline Characteristic & BEFA 8 & BEFA 15 \\
\hline Type & Analogical & Digital (serial) \\
\hline $\begin{array}{l}\text { Modulation } \\
\text { /transmission }\end{array}$ & Current pulses & FFSK FULL DÚPLEX \\
\hline Communication canal & three (3) copper pairs & One (1) copper pair \\
\hline Maximum reach & $13,5 \mathrm{Km}$ & $10 \mathrm{Km}$ \\
\hline Modulator & $\begin{array}{l}\text { Through relays makes current pulses given } \\
\text { by polarity inversion and potential } \\
\text { differences }\end{array}$ & FM Modulator \\
\hline $\begin{array}{l}\text { Maximum of } \\
\text { commands or } \\
\text { transmitted information }\end{array}$ & $\begin{array}{l}\text { Transmitted a maximum or } 8 \text { different } \\
\text { messages: } \\
\text { Pulse advance, disconnection pulse, } \\
\text { connection pulse, equipment failure pulse, } \\
\text { energy failure pulse, interconnection state } \\
\text { online pulse, synchronism pulse and } \\
\text { automatic pulse }\end{array}$ & $\begin{array}{l}\text { Allows the transmission of } 65536 \text { different } \\
\text { words (the mathematic result of the different } \\
\text { combinations of } 16 \text { bit, } 2^{\wedge} 16=65536 \text { ), inside } \\
\text { are highlight ; disconnection advance, plan } \\
\text { change, processor failure, intermediary times } \\
\text { failure, signaling failure for reds failure, } \\
\text { signaling failure for greens failure, intake } \\
\text { and voltage monitoring variation plan On- } \\
\text { line failure, state monitoring and clock } \\
\text { synchronism. }\end{array}$ \\
\hline
\end{tabular}

The traffic lights centers of Bogota D.C. city have a maximum nominal capability given by the manufacturing of 400 connected equipment that serve a simple intersection, clarify that the number of interconnected equipment by the center could vary accord to the dimension, to the quantity of groups that serve each control equipment and the quantity of planes and permissiveness of the approach that itself execute [6], The installed capability for each communication type and the total capability of the central systems according with the technical annexed of traffic lights of 31 of December of 2014 that shows in the following table

Table 1. Distribution of the installed capability for communication centrals management protocol on Bogota city Source [5]

\begin{tabular}{|l|r|r|r|r|}
\cline { 2 - 6 } \multicolumn{1}{c|}{} & \multicolumn{4}{c|}{ Distribution of control equipment for communication protocol } \\
\hline \multicolumn{1}{c|}{ Description } & \multicolumn{1}{c|}{ CHICÓ } & PALOQUEMA0 & \multicolumn{1}{c|}{ MUZÚ } & \multicolumn{1}{c|}{ TOTAL } \\
\hline BEFA 8 Equipment & 151 & 180 & 134 & 465 \\
\hline BEFA 15 Equipment & 192 & 180 & 169 & 541 \\
\hline DISPONIBLE BEFA 8 & 29 & 0 & 42 & 71 \\
\hline DISPONIBLE BEFA 15 & 0 & 12 & 23 & 35 \\
\hline TOTAL & 372 & 372 & $\mathbf{3 6 8}$ & 1112 \\
\hline
\end{tabular}

Given the previous table it could shows the following graphic

Figure 1. Distribution and control equipment connection for communication protocol type in each of the management traffic lights centers in the city of Bogota on December of 2014 [5]

In the city of Bogotá D.C. currently are installed equipment for 5 different generations and technologies according to his manufacturing date and design, this kind count with a common characteristic, they are capable of interconnecting with different traffic computers in the city [7], the equipment with the system counts in the ground are Siemens GE [8], Siemens MP [9], Siemens MR [10], Siemens Sitraffic C800V/C800Vk
[11] y Siemens Sitraffic C900V [12], which technical characteristics more relevant are showing in the following table [5]:

Table 1. Technical description of control equipment of local traffic. Source [5]

\begin{tabular}{|c|c|c|c|c|c|c|c|c|c|}
\hline \multirow{2}{*}{$\begin{array}{l}\text { Control } \\
\text { equipment }\end{array}$} & \multirow{2}{*}{$\begin{array}{c}\mathrm{N}^{0} \\
\text { Max. } \\
\text { groups. }\end{array}$} & \multirow{2}{*}{ Type } & \multirow{2}{*}{$\begin{array}{l}\text { Maximum } \\
\text { intersections }\end{array}$} & \multicolumn{2}{|c|}{$\begin{array}{l}\text { Minimal luminaire } \\
\text { Voltage }\end{array}$} & \multicolumn{2}{|c|}{ Communication Protocol } & \multirow{2}{*}{$\begin{array}{l}\text { Supports } \\
\text { ITS }\end{array}$} & \multirow{2}{*}{$\begin{array}{l}\text { Quantity } \\
\text { in } \\
\text { service }\end{array}$} \\
\hline & & & & $\begin{array}{l}\text { VALUE } \\
\text { (W) }\end{array}$ & TYPE & DESCRIPCTION & TYPE & & \\
\hline GE & 8 & analogous & 1 & 55 & Halogen & BEFA 8 & analogous & NO & 161 \\
\hline MP & 16 & analogous & 1 & 55 & Halogen & BEFA 8 & analogous & N0 & 282 \\
\hline MR & 24 & Digital & 2 & 12 & LED & $\begin{array}{c}\text { BEFA 8/BEFA } \\
15\end{array}$ & $\begin{array}{c}\text { analogous } \\
\text { /Digital }\end{array}$ & NO & 234 \\
\hline C800V/NK & 32 & Digital & 4 & 12 & LED & $\begin{array}{c}\text { BEFA 8/BEFA } \\
15\end{array}$ & $\begin{array}{c}\text { analogous } \\
\text { /Digital }\end{array}$ & YES & 332 \\
\hline C900V & 32 & Digital & 4 & 12 & LED & BEFA 15 & Digital & YES & 46 \\
\hline
\end{tabular}

The traffic lights centers of Bogota D.C. city have a maximum nominal capability given by the manufacturing of 400 connected equipment that serve a simple intersection, clarify that the number of interconnected equipment by the center could vary accord to the dimension, to the quantity of groups that serve each control equipment and the quantity of planes and permissiveness of the approach that itself execute [6], The installed capability for each communication type and the total capability of the central systems according with the technical annexed of traffic lights of 31 of December of 2014 that shows in the following table

Table 1. Distribution of the installed capability for communication centrals management protocol on Bogota city Source [5]

\begin{tabular}{|r|r|r|r|r|}
\cline { 2 - 5 } \multicolumn{1}{c|}{} & \multicolumn{5}{c|}{ Distribution of control equipment for communication protocol } \\
\hline \multicolumn{1}{|c|}{ Description } & CHICÓ & PALOQUEMA0 & \multicolumn{1}{c|}{ MUZÚ } & \multicolumn{1}{c|}{ TOTAL } \\
\hline BEFA 8 Equipment & 151 & 180 & 134 & 465 \\
\hline BEFA 15 Equipment & 192 & 180 & 169 & 541 \\
\hline DISP0NIBLE BEFA 8 & 29 & 0 & 42 & 71 \\
\hline DISPONIBLE BEFA 15 & 0 & 12 & 23 & 35 \\
\hline TOTAL & 372 & 372 & 368 & 1112 \\
\hline
\end{tabular}

Given the previous table it could shows the following graphic 
Proc. of the Fourth International Conference on Advances in Computing, Electronics and Communication - ACEC 2016. Copyright (C) Institute of Research Engineers and Doctors. All rights reserved.

ISBN: 978-1-63248-113-9 doi: 10.15224/ 978-1-63248-113-9-55

Figure 2. Distribution and control equipment connection for communication protocol type in each of the management traffic lights centers in the city of Bogota on December of 2014 [5]

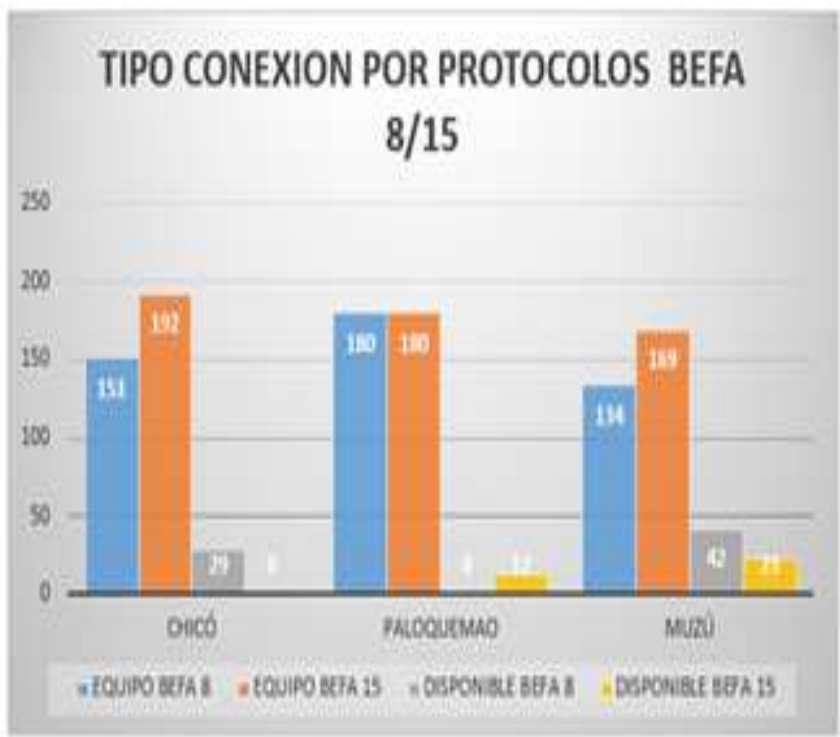

In the city of Bogotá D.C. currently are installed equipment for 5 different generations and technologies according to his manufacturing date and design, this kind count with a common characteristic, they are capable of interconnecting with different traffic computers in the city [7], the equipment with the system counts in the ground are Siemens GE [8], Siemens MP [9], Siemens MR [10], Siemens Sitraffic C800V/C800Vk [11] y Siemens Sitraffic C900V [12], which technical characteristics more relevant are showing in the following table [5]:

Table 1. Technical description of control equipment of local traffic. Source [5]

\begin{tabular}{|c|c|c|c|c|c|c|c|c|c|}
\hline \multirow{2}{*}{$\begin{array}{l}\text { Control } \\
\text { equipment }\end{array}$} & \multirow{2}{*}{$\begin{array}{c}\mathrm{N}^{\circ} \\
\text { Max. } \\
\text { groups. }\end{array}$} & \multirow{2}{*}{ Type } & \multirow{2}{*}{$\begin{array}{l}\text { Maximum } \\
\text { intersections }\end{array}$} & \multicolumn{2}{|c|}{$\begin{array}{c}\text { Minimal luminaire } \\
\text { Voltage }\end{array}$} & \multicolumn{2}{|c|}{ Communication Protocol } & \multirow{2}{*}{$\begin{array}{c}\text { Supports } \\
\text { ITS }\end{array}$} & \multirow{2}{*}{$\begin{array}{l}\text { Quantity } \\
\text { in } \\
\text { service }\end{array}$} \\
\hline & & & & $\begin{array}{l}\text { VALUE } \\
(\mathrm{W})\end{array}$ & TYPE & DESCRIPCTION & TYPE & & \\
\hline GE & 8 & analogous & 1 & 55 & Halogen & BEFA 8 & analogous & N0 & 161 \\
\hline MP & 16 & analogous & 1 & 55 & Halogen & BEFA 8 & analogous & NO & 282 \\
\hline MR & 24 & Digital & 2 & 12 & LED & $\begin{array}{c}\text { BEFA 8/BEFA } \\
15\end{array}$ & $\begin{array}{c}\text { analogous } \\
\text { /Digital }\end{array}$ & NO & 234 \\
\hline C800V/VK & 32 & Digital & 4 & 12 & LED & $\begin{array}{c}\text { BEFA 8/BEFA } \\
15\end{array}$ & $\begin{array}{c}\text { analogous } \\
\text { /Digital }\end{array}$ & YES & 332 \\
\hline $\mathrm{C} 900 \mathrm{~V}$ & 32 & Digital & 4 & 12 & LED & BEFA 15 & Digital & YES & 46 \\
\hline
\end{tabular}

Currently Bogota counts with three control and monitoring centers already mentioned, 1055 equipment for controlling a total of 1301 intersections, which are of the SIEMENS S.A. provider distributed like this:

\begin{tabular}{|c|c|c|c|c|c|c|}
\hline \multicolumn{6}{|c|}{ QUANTITY OF CONTROL EQUIPMENT } \\
\hline EQUIPMENT & CHIC0 & PALOQUEMA0 & MUZÚ & BOG0TÁ D.C. & TECHNOLOGY \\
\hline GE & 53 & 70 & 38 & 161 & ANCIENT \\
\hline MP & 88 & 100 & 94 & $\mathbf{2 8 2}$ & ANCIENT \\
\hline MR & 104 & 76 & 54 & 234 & ANCIENT \\
\hline C800V & 81 & 72 & 77 & 230 & NEW \\
\hline C800VK & 34 & 22 & 46 & 102 & NEW \\
\hline C900V & 9 & 19 & 18 & 46 & NEW \\
\hline T0TAL & 369 & 359 & 327 & 1055 & \\
\hline
\end{tabular}

Table 1. Distributed of control equipment in Bogota D.C city to December of 2014 Source [5].

According the information, it could show the following graphics 




\section{INTEGRATION PROPOSAL OF THE EXISTING EQUIPMENT TO A SYSTEM BASED IN AENOR PROTOCOL}

The proposal solution allows the integration of the different traffic control equipment to a new traffic central keeping the currently existing characteristics in Bogota D.C., the solution is supported in a emulation system of a M56 central, such as those Bogota D.C. city currently counts

Given the theft vulnerability of the copper pair material existing that compose the interconnection network of the traffic lights system, this paper proposes implement a solution directly inside the control equipment (pro-equipment device) or in the last $\mathrm{km}$ of the copper network (distributor by zonas or networks). Such devices must count with synchronism given by GPS systems or inherited of the centralized control own of the AENOR protocol with the goal of guarantee the reliability of the signals that control the centralized behavior of each traffic control equipment. According above each equipment must count with an IP terminal who allows connecting the BEFA protocol and will available in the moment of make the AENOR migration protocol.

\section{BEFA protocol integration:}

Given the 15 BEFA protocol technical characteristics, showed in the table 2, that use a Half Duplex configuration and FFSK digital modulation with a maximum frequency of 2400 Hz. It proposes make a simulation of the central through the signal going and return network procurement, based in a time analysis and generating a proof protocol with the goal of identify the frames that allows the control of the equipment from de central.

The communication channel analysis must to be done through a digital oscilloscope or acquisition system with capability of generate files based in time which could play and make treatment digital. The above with goal of identify each one of the send frames by the central and the equipment according to the proof conditions.
Equally must guarantee the impedance coupling between the 15 BEFA copper pairs channel of system and the data acquisition system, assuming that the transmission is similar to the structure of a telephonic system.

On time acquires the data and processing the information it must generate a proof protocol through which from a calculation equipment allows simulate the M56 central supported in a BEFA 15 protocol and guarantee the control of the system function

To overcome successfully the equipment control proofs through a calculation system, must develop a AENOR protocol based device, that was a remote terminal with capability of concocted through an IP network with the AENOR central and simulate the existing of a control central based on 15 BEFA protocol for copper pair and it was connected to the equipment controlling the majir quantity of available functions.

Define abbreviations and acronyms the first time they are used in the text, even after they have been defined in the abstract. Abbreviations such as IEEE, SI, MKS, CGS, sc, dc, and rms do not have to be defined. Do not use abbreviations in the title or heads unless they are unavoidable.

\section{The hardware configuration proposed is composed}

- A high performance analogical digital conversion integrated circuit used in audio, or a signal acquisition system, example Hantek6222BE [13].

- The control unit propose a high performance microcontroller, with capability of Ethernet via connection by IP protocol, this solution could have integrated through a microprocessor terminal connected to a protocols adapter, being adapter to protocols TCP/IP could be used through a SPI communication protocol with the control unit ENC28J60 or through UART communication protocol with the UART-TCP/IP NEMO 10 converter of the manufacturer SENA [14].

- The coupling between the transmission pair of the traffic control equipment through 15 BEFA protocol and the communication system developed propose the given solution in the application note AN854 "Connecting a PICmicro Microcontroller to a Standard Analog Telephone Line" de Microchip Technology Inc[15]. 


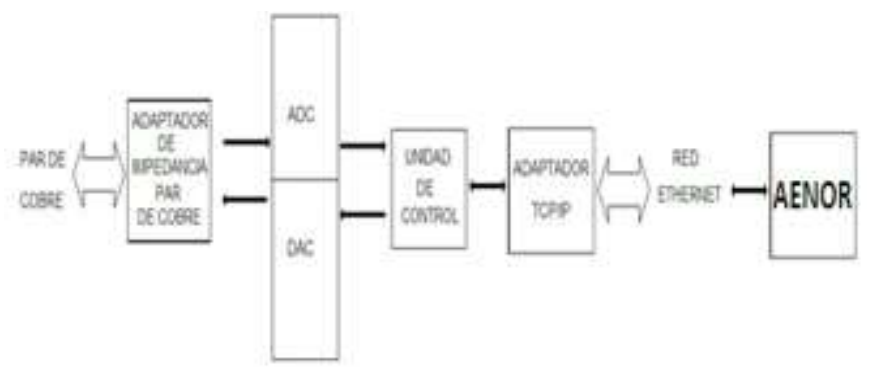

Figure 3. blocks diagram of the 15 BEFA solution Source: Own elaboration

\section{BEFA 8 integration protocol}

Given the BEFA 8 protocol characteristics must integrated the protocols unit to the possibility of generate and receive current signals or OP3/OP2 pulses based in the same architecture and procedures of BEFA 15 device

\section{Traffic planning integration}

Achieving the physic level integration between the control equipment and the traffic central simulating, the planning characteristics are migrated having account as base the synchronism pulse advances characteristics and advance that currently is used in the centralized control through normal RILSA [16], both for BEFA 8 as for BEFA 15, allowing a controlled and planed migration toward the new traffic control protocol in the city.

Equally based in the study of both protocols (BEFA and AENOR) its performed a similarities and correlations parallel between the functions designed to software and hardware systems level of translation with the goal of minimize the differences between the technologies

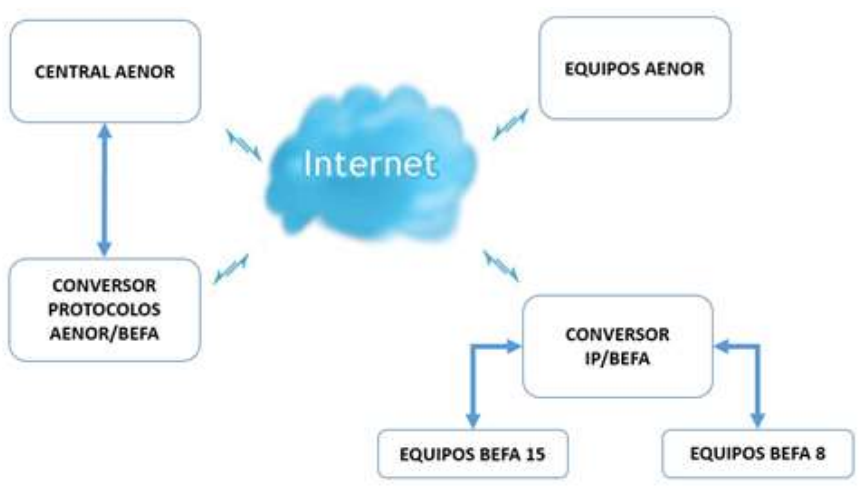

Figure 4.Propose model for system integration Source: Own elaboration

\section{Testing proposal}

Once develop the system its propose make technique tests in controlled environments, through the installation of a traffic control equipment programed for both BEFA 15 and BEFA 8 protocol, measuring behavior variables and system answers. Finishing in an intersection or proof corridor that preferably it's found outside the interconnection system of Bogota with the goal of show the development efficiency.

\section{Controlled Environment Tests}

The testing in controlled environment must include the following elements

\begin{tabular}{|c|l|l|}
\hline ÍTEM & \multicolumn{1}{|c|}{ TEST } & \multicolumn{1}{|c|}{ EXPECTED RESULT } \\
\hline 1 & $\begin{array}{l}\text { Control through a system } \\
\text { that simulate the central } \\
\text { signals (Central by software) }\end{array}$ & $\begin{array}{l}\text { The equipment must be detecting the central as a M56 and } \\
\text { received orders according the programed protocol, equally } \\
\text { must transmitted the requires information by the central } \\
\text { without differentiate between the traffic central in the proof } \\
\text { system }\end{array}$ \\
\hline 2 & $\begin{array}{l}\text { Control through the signal } \\
\text { transmitted issued by the } \\
\text { M56 equipment (data } \\
\text { transmission layer) }\end{array}$ & $\begin{array}{l}\text { The design system must be in capability of translate send } \\
\text { orders by the M56 center and send it to the equipment through } \\
\text { a LAN network and equally answer to the central, being the } \\
\text { transparent system installation both for the central as for } \\
\text { control equipment }\end{array}$ \\
\hline 3 & $\begin{array}{l}\text { Control from AENOR } \\
\text { protocol }\end{array}$ & $\begin{array}{l}\text { The develop system must be in the capability of received } \\
\text { orders from a AENOR central and emit orders to the equipment } \\
\text { in BEFA 8/15, according the case, and answer to the central } \\
\text { with the previously programed orders in the control dictionary. }\end{array}$ \\
\hline
\end{tabular}

\section{FIELD TEST OR REAL CONDITION TEST}

The field test must include the following elements:

\begin{tabular}{|c|l|l|}
\hline ÍTEM & \multicolumn{1}{|c|}{ TEST } & \multicolumn{1}{|c|}{ EXCEPCTED RESULT } \\
\hline 1 & $\begin{array}{l}\text { Control through a system } \\
\text { that emulate the central } \\
\text { signals (Central by } \\
\text { software) }\end{array}$ & $\begin{array}{l}\text { The equipment or the equipment network must detect the central } \\
\text { as M56 and receive the orders according the programed protocol, } \\
\text { equally must transmit the requires information by the central } \\
\text { without make difference between the traffic center and the test } \\
\text { system. Important have in count the time fulfilment and the answer } \\
\text { verification in front of the equipment failure }\end{array}$ \\
\hline 2 & $\begin{array}{l}\text { Control through the } \\
\text { transmission of a signal } \\
\text { emitted by M56 } \\
\text { equipment } \\
\text { transmission layer) }\end{array}$ & $\begin{array}{l}\text { The design system must be in the capability of translate orders send } \\
\text { by M56 central and send it to the equipment through a LAN } \\
\text { network and equally answer to the central, being the installation } \\
\text { transparent system both for central and for control equipment }\end{array}$ \\
\hline 3 & $\begin{array}{l}\text { Control from AENOR } \\
\text { protocol }\end{array}$ & $\begin{array}{l}\text { The developed system must be in capability of receive orders from } \\
\text { a AENOR central and emitted to the equipment orders to a BEFA } \\
\text { protocol }\end{array}$ \\
\hline
\end{tabular}

\section{Testing proposal}


Given the test it considers successfully if for one established protocol of failures and orders in each one of the test shows reliability and the answer, integrated equipment in isolated networks at the same ways. It should be noted that the equipment must be testing in first place in directly connection with the M56 central becoming this test as the measuring unit front the assay to make.

\section{RISK MITIGATION}

According to the Secretaria Distrital de Hacienda Resolution No. 866 of 8 September of 2004 through which is adopted "Procedures Manual for the Management of contingent liabilities in Bogotá D.C.'[17] And the CONPES No 3107 published on April 3, 2001 by which the "Contract Management Policy Risk Processes State for Private Participation in Infrastructure is adopted" [18] , are identify the following risk:

\begin{tabular}{|l|l|}
\hline ITEM & RISK \\
\hline 1 & Commercial \\
\hline 2 & $\begin{array}{l}\text { Construction risk in the physical } \\
\text { infrastructure }\end{array}$ \\
\hline 3 & Operation risk \\
\hline 4 & Financial risk \\
\hline 5 & \\
\hline
\end{tabular}

\section{References}

[1] A. V. Méndez, "Desarrollo De Una Metodología Para El Control De La Señalización del tráfico y el sistema de semaforización.” BOGOTA D.C., 2009.

[2] B. Klaus, "A. HARWARE," in CURSO MANTENIMIENTO HARDWARE SICOMP, SEGUNDA., SIEMENS AG, Ed. 1994, p. 51.

[3] EMPRESA DE TELEFONOS DE BOGOTA ETB, "CAPITULO 8. EAANSCHULBSTELLEN-UMSCHALTER," in PROGRAMA DE SEMAFORIZACION, CURSO PARA BOGOTA, PRIMERA., BOGOTA D.C., 1985, p. 5.

[4] Tion Semiconductors, "CMX469A," no. June. 2009.

[5] E. Chávez Ayala, "Estudio de las características técnicas de los computadores de tráfico y los equipos control de tráfico local del sistema de Semaforización de Bogotá D.C. proyectando su integración a un Sistema Inteligente de Trafico (SIT) de acuerdo a las necesidades de." BOGOTA D.C., p. 127, 2015.

[6] SIEMENS SA, "capitulo 2: L6000 CONTROLADORES EN BEFA," in PROGRAMACION EQUIPO DE CONTROL DE TRAFICO, PRIMERA., SIEMENS SA, Ed. BOGOTA D.C., 1995, p. 80.

[7] Secretaría Distrital de Movilidad, "ESTUDIOS PREVIOS MANTENIMIENTO PREVENTIVO Y CORRECTIVO DE COMPUTADORES DE TRÁFICO Y SUS PERIFERICOS, EQUIPOS DE CONTROL LOCAL Y CONEXIÓN DE MÓDULOS
EVALUADORES DE TRÁFICO DEL SISTEMA DE SEMAFORIZACIÓN DE BOGOTÁ D.C.” BOGOTA D.C., p. 28, 2014.

[8] B. Jairo and B. Klaus, "Siemens proyectos industriales, introducción a los equipos de control de tráfico, Equipo de control de tráfico GE.".

[9] B. Jairo and B. Klaus, "Siemens proyectos industriales, introducción a los equipos de control de tráfico, Equipo de control de tráfico MP.".

[10] Bastidas Jairo and B. Klaus, "Siemens proyectos industriales, introducción a los equipos de control de tráfico, Equipo de control de tráfico MR, capacitación equipo de control MR, Bogotá DC.”.

[11] SIEMENS SA, "SITRAFFIC C800V, Guía de operación para el controlador C800V y detector LD4.".

[12] SIEMENS SA, "SITRAFFIC C9X0, PRODUCT OVERVIEW TRAFFIC CONTROLLER, DESCRIPCION Y MANUAL DE OPERACION.".

[13] L. Qingdao Hantek Electronic Co., "Hantek6222BE User's Manual." Qingdao City, Shandong Province, China, p. 58, 2010.

[14] I. SENA TECHNOLOGIES, "UART-TCP/IP NEMO 10," vol. 13. pp. $54-55$.

[15] D. Hedley, "Connecting a PICmicro ${ }^{\circledR}$ Microcontroller to a Standard Analog Telephone Line." pp. 1-4, 2002.

[16] UNIVERSIDAD NACIONAL DE COLOMBIA, "PLAN INTEGRAL DE TRÁNSITO Y TRANSPORTE ETAPA 1: RECOLECCIÓN DE INFORMACIÓN Y DIAGNÓSTICO DE LA OPERACIÓN DEL TRÁNSITO Y EL TRANSPORTE EN EL MUNICIPIO DE YOPAL INFORME FINAL.” 2005.

[17] SECRETARIA DISTRITAL DE HACIENDA DE BOGOTA, "Resolucion 886 de 2004.pdf." p. 46, 2004.

[18] DEPARTAMENTO NACIONAL DE PLANEACION, "CONPES 3107 Política de Riesgo Contractual del Estado para Procesos de Participación Privada en Infraestructura." p. 28, 2001.

About Author (s):



[Type a quote from the document or the summary of an interesting point. You can position the text box anywhere in the document. Use the Drawing Tools tab to change the formatting of the pull quote text box.] 